\title{
Carbon stock density in planted versus natural Pinus massoniana forests in sub-tropical China
}

\author{
Long-Chi Chen $^{1,2} \cdot$ Meng-Jie Liang ${ }^{1,3} \cdot$ Si-Long Wang ${ }^{1,2,4}$
}

Received: 25 August 2015 / Accepted: 26 January 2016 / Published online: 9 March 2016

(C) INRA and Springer-Verlag France 2016

\begin{abstract}
- Key message Carbon stock density was quite similar in planted vs natural forest of Masson's pine (Pinus massoniana Lamb.) in China across three ages $(7,15$, and 50 years). The stock in the standing trees was larger in planted than in natural forests, but this difference was compensated by larger stocks in the soil and the debris of natural forests.

- Context Most studies on the carbon stocks are focused on management strategies to maximize carbon stocks. We still lack data comparing planted vs natural conifer forests.

- Aims We compared carbon storage in the different compartment (vegetation, soil, debris) along a chronosequence of Masson's pine plantations vs natural forests.

- Methods We investigated 58 Masson's pine (Pinus massoniana Lamb.) forest stands (20 $\mathrm{m} \times 50 \mathrm{~m}$ plots $)$, that

Shuqing Zhao

Contribution of the co-authors Long-Chi Chen designed the experiment, wrote the manuscript, participated to the field work, and performed the statistical analysis in SPSS. Meng-Jie Liang gave a contribution to form all tables and figures. Si-Long Wang coordinated the research project, provided funding to this experiment, and supervised the final version of the manuscript
\end{abstract}

Si-Long Wang

slwang@iae.ac.cn

1 Institute of Applied Ecology, Chinese Academy of Sciences, Shenyang 110164, China

2 Huitong Experimental Station of Forest Ecology, Chinese Academy of Science, Huitong 418307, China

3 University of Chinese Academy of Science, Beijing 100039, China

4 Wenhua Road 72, Shenhe District, Shenyang, Liaoning Province 110016, China differ in stand management (planted and natural forests) and age (young, middle-aged, and mature ages) and then calculated the carbon stock densities of vegetation biomass (tree, shrub, and herb), debris, and soil.

- Results The carbon stock densities in the planted and natural Masson's pine forest ecosystems ranged from 78 to $210 \mathrm{Mg} \mathrm{ha}^{-1}$ and from 97 to $177 \mathrm{Mg} \mathrm{ha}^{-1}$ respectively. The carbon stock densities in the vegetation were significantly greater in planted forests than in natural forests. A lower carbon stock density in debris and soil alleviated the increase of biomass carbon stock densities in planted vs natural forests, leading to similar carbon stock densities at ecosystem level. The carbon stock densities in the vegetation increased with age, whereas those of debris and soil remained stable.

- Conclusions Planted forests of Masson's pine sequester similiar amounts of carbon at ecosystem level to those in natural forests, reinforcing the idea that planted pine forests can contribute to the mitigation of greenhouse gas emission.

Keywords Planted forest · Natural forest - Carbon stock density $\cdot$ Carbon sequestration $\cdot$ Soil organic carbon

\section{Introduction}

Due to the expansion of forests, forest practices such as afforestation and reforestation seem to be effective measures for sequestering carbon from the atmosphere and mitigating global climate change (Winjum and Schroeder 1997). Afforestation and reforestation are also proposed in Article 3.3 of the Kyoto Protocol as effective methods of carbon sequestration. In contrast to the decreasing land areas of primary forest and other naturally regenerated forests, the land areas of planted forests are increasing, making up to approximately $7 \%$ of the global forest area (FAO 2010). Between 2000 
and 2010, the global area of planted forest increased by approximately 5 million hectares per year, and most of them were established through afforestation (FAO 2010). As a result of its ongoing afforestation efforts, China's afforestation is now the largest in the world, constituting more than $26 \%$ of the world-wide planted forest area (Del Lungo et al. 2006). The annual net gain in planted forest area in China has increased by 2 million hectares per year during the period 1990-2000 and by an average of 3 million hectares per year since 2000 (FAO 2010). The area of the planted forests also accounts for approximately $31.7 \%$ of the total forest area in China (State Forestry Administraiton 2009) and continues to increase because of the Grain for Green Program of China (Liu et al. 2008). Moreover, afforestation offers a great potential for atmospheric $\mathrm{CO}_{2}$ sequestration. Following afforestation, carbon stocks in the above- and below-ground plant biomass in planted forests increase significantly with forest age (Niu and Duiker 2006). Although soils accumulate less carbon at a slower rate than the aboveground biomass (Jandl et al. 2007), soils can contribute approximately $30 \%$ of the total carbon sequestered in afforested ecosystems, as suggested by a synthesis of afforestation chronosequences in northwestern Europe (Vesterdal et al. 2006). Consequently, planted forests play an increasingly important role in carbon sequestration in China. Studies on the carbon stock density of planted forests, especially when compared with that of natural forests, will deepen our understanding of the role of planted forests in carbon sequestration.

With the decrease in the land area of natural forests and the increase in the land area of planted forests, the need to determine whether the planted forests exhibit ecosystem productivity and carbon stock similar to those of natural forests has drawn much attention (Chen et al. 2005; Guo and Ren 2014; Liao et al. 2010; Perez-Quezada et al. 2011; Thornley and Cannell 2000). Whether carbon sequestration is greater in natural or in planted forests is debated. Thornley and Cannell (2000) found that regular forest management strategies, such as harvesting (removal of 10 or $20 \%$ of woody biomass), can gain both a high timber yield and high carbon storage, and then sequester carbon. This is attributed to higher light interception and net primary productivity, higher litter input to the soil giving high soil carbon and $\mathrm{N}_{2}$ fixation, and lower maintenance respiration than in the undisturbed forest. Guo and Ren (2014) reported that plantations exhibit much higher productivity, and thus, much higher carbon sequestration rates than natural forests. However, Liao et al. (2010) suggested that the ecosystem carbon stock of plantations is reduced by $28 \%$ compared with the natural forests. Perez-Quezada et al. (2011) also reported that carbon pools in an arid shrub land are higher under natural conditions than under afforested conditions. The above-mentioned information on the differences in carbon sequestration of natural and planted forests may have been misguided by many factors; thus, opposing results were obtained. The first factor is the tree species. Different tree species exert different effects on the improvement of productivity and carbon sequestration (Tang and Li 2013; Wang et al. 2013). Broadleaved tree species can usually sequester greater amounts of carbon than coniferous tree species (Wang et al. 2013), thereby leading to the higher carbon stocks stored in ecosystems following afforestation of hardwoods, such as Eucalyptus, than afforestation of softwoods, such as pine ( $\mathrm{Li}$ et al. 2012). Most of the natural forests reported in the above mentioned studies are natural broadleaved forests dominated by native broadleaved tree species. However, the most common tree species in planted forests are coniferous tree species, such as Cunninghamia lanceolata, Pinus caribaea, P. massoniana, P. radiata, and Picea abies (Liao et al. 2010). The second factor is forest management. Thornley and Cannell (2000) suggested that management regimes maintaining a continuous canopy cover and mimicking regular natural forest intervention are likely to gain the best combination of high wood yield and carbon storage. Stand age can also affect the calculation of carbon stock of forests. Guo and Ren (2014) suggested that stand ages can explain the differences in the performance of planted and natural forests. They found that the productivity of plantations is twice that of natural forests because the plantations are still in their early stages of succession. However, the comparison of the carbon stocks of planted and natural forests of different ages leads to a biased or even erroneous result. Stand condition can also affect forest productivity and carbon sequestration. Moreover, clayrich soils $(>33 \%)$ exhibit a greater capacity to accumulate soil organic carbon than soil with lower clay content $(<33 \%)$ (Laganière et al. 2010). For the above reasons, most of the previous comparisons are incomplete and the scenario of natural broadleaved forests versus planted coniferous forests is usually missing, leading to a biased result that influences our knowledge on which between the planted forests with management practices and natural forests sequester more carbon.

Masson's pine (P. massoniana Lamb.) is native to China and is widely distributed in the northern latitudes (Yang et al. 2011). Although few studies have reported on the stand biomass of Masson's pine forests in China (Ding and Wang 2001; Liu 1996; Mo et al. 1999), none of them has directly compared the carbon stock densities of planted and natural Masson's pine forests at various ages. The comparison of carbon stock densities of planted and natural pine forests could redefine the role of planted and natural forests in carbon sequestration, leading to a conclusion concerning which one has more potential in mitigating climate change, in order to better increase carbon sink of management forests. To compare the carbon stock densities of planted and natural forests, we selected 58 plots of planted and natural Masson's pine forests in a series of stands at different ages. We hypothesized that planted forests exhibit fundamental differences in terms of carbon stock density and distribution pattern from the natural forests, such as 
more carbon stock density stored in planted forests than in natural forests, and these differences are mainly caused by stand treatments and forest management. The study specifically aims to quantify the carbon stock densities and their proportions in the planted and natural Masson's pine forests at different ages, and to determine the changes of their carbon stock densities following a chronosequence. A comparison of the changes of carbon stock densities between planted and natural Masson's pine forest ecosystems with age is critical in understanding the role of reforestation and afforestation in mitigating global climate change.

\section{Materials and methods}

\subsection{Site description and plot selection}

Field work was conducted in Hunan Province $\left(108^{\circ} 47^{\prime}-\right.$ $\left.114^{\circ} 15^{\prime} \mathrm{E}, 24^{\circ} 38^{\prime}-30^{\circ} 08^{\prime} \mathrm{N}\right)$ situated in the mid-subtropical zone of China (Fig. 1). Hunan Province is located at the transition zone from the Yunnan-Guizhou plateau to the lower mountains and hills along the southern side of the Yangtze River at an elevation of 21-2122 $\mathrm{m}$ above sea level. The climate of this region is humid, mid-subtropical monsoon. The mean annual precipitation is $1,200-1,700 \mathrm{~mm}$, approximately $68-84 \%$ of which is received between April and October. The mean annual air temperature is $16{ }^{\circ} \mathrm{C}-18^{\circ} \mathrm{C}$, with mean minimum in January and mean maximum in July. The soil derived from shale and slate is red-yellow and is classified as Plinthudults, a subgroup of Ultisols according to US Soil Taxonomy (Wang et al. 2013). The soil also exhibits a grayish upper horizon found above the reddish argillic horizon.

Masson's pine (P. massoniana Lamb.) is widely distributed in the north latitudes $\left(21^{\circ} 41^{\prime}-33^{\circ} 51^{\prime}\right)$ of China (Yang et al. 2011). Due to its widespread use in turpentine, building, and paper, Masson's pine is a common reforestation tree species, comprising $20 \%$ of the plantations in China (Mo et al. 1999). Masson's pine is also a pioneer tree species in forest succession because of its high adaptability and tolerance to drought and impoverished soils. In Hunan Province in southern China, Masson's pine occurs in 0.81 million hectares of natural forests and 0.32 million hectares of plantations (Forestry Department of Hunan Province 2010). Forest management practices are implemented in planted forests at each age. Understory species are removed to increase the survival rate of seedlings in the planted Masson's pine forests at a young age. Tree thinning is also usually performed to enhance forest productivity in young and middle-aged trees. Sometimes, fertilization is a common management practice in planted Masson's pine forests. By contrast, no forest management practice is implemented in the natural pine forests, and a lower intensity of human intervention, such as fire wood collection and grazing by cattles, occasionally appears in natural Masson's pine forests in Hunan Province.

The design of this study incorporates two factors: stand management (planted and natural forests) and stand age. Table 1 shows the number of plots (replicates) of planted and natural forests. The presence of naturally occurring Masson's pine forest characterizes the early stage of forest succession in the subtropical zone of China (Fang et al. 2011; Yan et al. 2009; Zeng et al. 2013). Given the implementation of the Natural Forest Conservation Program in China,
Fig. 1 Location of planted and natural Masson's pine forests in Hunan Province, China. The hollow legends are the locations of planted forests; the solid legends are the locations of natural forests. The number associated with each legend indicates the number of overlapping forest stands (although the distances between stands representing each forest type were more than $1 \mathrm{~km}$, many sites of forest stands were overlapped on the map of Hunan Province)

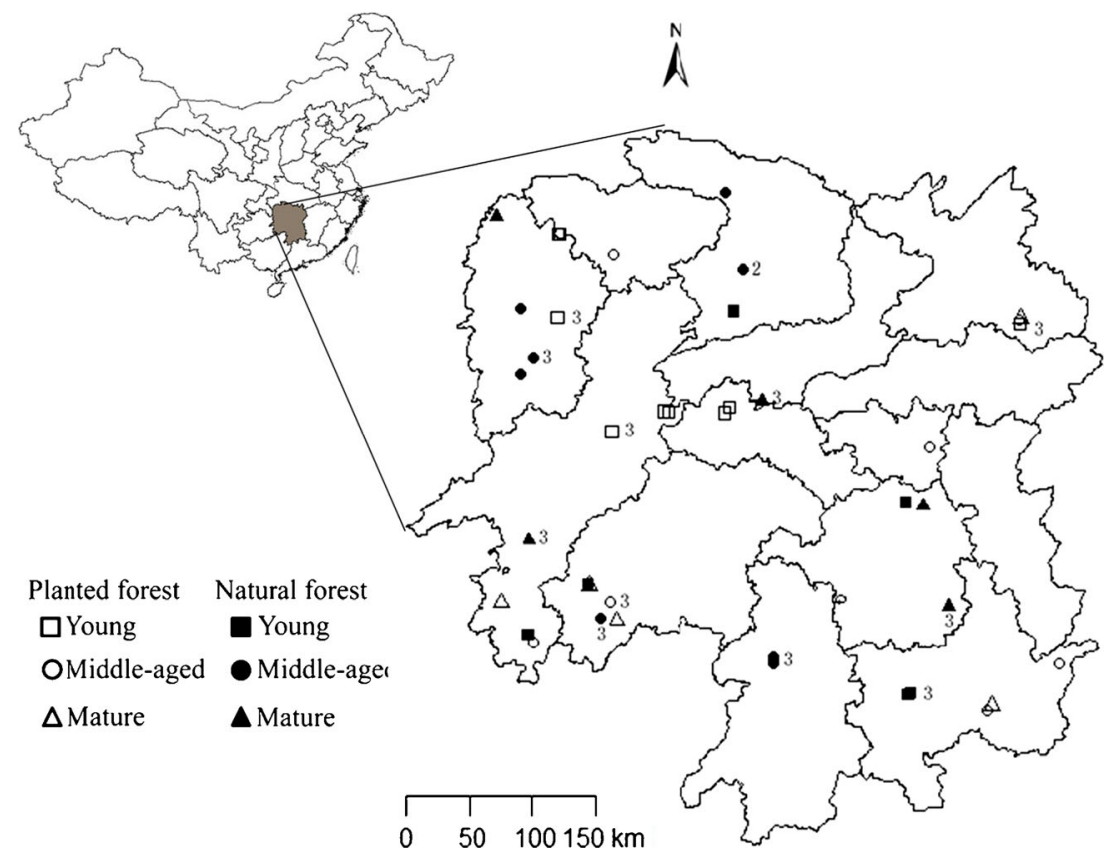


Table 1 Characteristics of the Masson's pine forests at different ages

\begin{tabular}{|c|c|c|c|c|c|c|}
\hline \multirow[t]{2}{*}{ Item } & \multicolumn{2}{|l|}{ Young forest } & \multicolumn{2}{|c|}{ Middle-aged forest } & \multicolumn{2}{|l|}{ Mature forest } \\
\hline & Planted & Natural & Planted & Natural & Planted & Natural \\
\hline Replicates & 13 & 7 & 9 & 13 & 5 & 11 \\
\hline Age (years) & $6 a$ & $8 \mathrm{ab}$ & $14 \mathrm{ab}$ & $17 \mathrm{~b}$ & $48 \mathrm{c}$ & $52 \mathrm{c}$ \\
\hline Slope $\left(^{\circ}\right)$ & $12 \mathrm{a}$ & $15 \mathrm{a}$ & $18 \mathrm{a}$ & $13 \mathrm{a}$ & $11 \mathrm{a}$ & $12 \mathrm{a}$ \\
\hline Elevation (m) & $313 a$ & $313 a$ & $414 \mathrm{a}$ & $297 \mathrm{a}$ & $379 a$ & $338 \mathrm{a}$ \\
\hline Canopy closure (\%) & $75 \mathrm{a}$ & $50 \mathrm{~b}$ & $60 \mathrm{ab}$ & $70 \mathrm{ab}$ & $60 \mathrm{ab}$ & $50 \mathrm{~b}$ \\
\hline $\mathrm{DBH}(\mathrm{cm})$ & $6.2 \mathrm{a}$ & $8.4 \mathrm{a}$ & $15.3 b$ & $14.0 \mathrm{~b}$ & $25.5 \mathrm{c}$ & $23.2 \mathrm{c}$ \\
\hline Height (m) & $4 \mathrm{a}$ & $5 a$ & $11 b$ & $10 \mathrm{~b}$ & $20 \mathrm{c}$ & $15 \mathrm{~d}$ \\
\hline Stand density (stems ha ${ }^{-1}$ ) & $2,353 a$ & $1,335 \mathrm{ab}$ & $1,522 \mathrm{ab}$ & $1,329 \mathrm{ab}$ & $723 b$ & $986 \mathrm{~b}$ \\
\hline Soil taxonomy & Ultisol & Ultisol & Ultisol & Ultisol & Ultisol & Ultisol \\
\hline SOC in $0-10 \mathrm{~cm}\left(\mathrm{~g} \mathrm{~kg}^{-1}\right)$ & $13.4(2.0) \mathrm{a}$ & $22.7(1.5) b$ & $21.6(3.4) \mathrm{b}$ & 21.2(1.9)b & $22.9(1.9) \mathrm{b}$ & $23.6(2.0) \mathrm{b}$ \\
\hline $\mathrm{STN}$ in $0-10 \mathrm{~cm}\left(\mathrm{~g} \mathrm{~kg}^{-1}\right)$ & $1.2(0.1) \mathrm{a}$ & $1.1(0.2) \mathrm{a}$ & $1.8(0.3) \mathrm{a}$ & $1.5(0.2) \mathrm{a}$ & $1.4(0.3) \mathrm{a}$ & $1.7(0.2) \mathrm{a}$ \\
\hline $\mathrm{STP}$ in $0-10 \mathrm{~cm}\left(\mathrm{~g} \mathrm{~kg}^{-1}\right)$ & $0.38(0.03) \mathrm{a}$ & $0.21(0.03) \mathrm{b}$ & $0.33(0.06) \mathrm{ab}$ & $0.29(0.03) \mathrm{ab}$ & $0.23(0.03) \mathrm{ab}$ & $0.36(0.03) \mathrm{ab}$ \\
\hline
\end{tabular}

Values with different letters $(\mathrm{a}, \mathrm{b}$, and $\mathrm{c})$ denote significant difference between planted and natural forests at the same ages or among the same management forests at different ages $(p<0.05$ based on Tukey's honestly significant difference test). Values in parentheses are standard errors of the means. SOC, STN, and STP are the abbreviation of soil organic carbon, soil total nitrogen, and soil total phosphorus

finding planted Masson's pine forests established on cleared natural forests is challenging. Thus, the Masson's pine forest plantations we selected were commonly established after clear-cutting and slash-burning the existing Chinese fir plantation, even if they were different from the land-use history of natural Masson's pine forests. The stand ages used in studies are as follows: young ( $\leq 10$ years), middle-aged ( $>10$ and $\leq$ 20 years), and mature ( $>20$ years), which are consistent with those used by the State Forestry Administration of China. In addition, the distance between stands representing each forest type was more than $1 \mathrm{~km}$ (Fig. 1). Table 1 shows the main characteristics of each chronosequence.

At present, the tree species composition of the planted and natural Masson's pine forests is dominated by P. massoniana Lamb. The dominant shrub species in the planted pine forests include Quercus glandulifera var. brevipetiolata Nakai, Loropetalum chinense, and Q. fabri Hance. Those in the natural pine forests include $Q$. glandulifera var. brevipetiolata Nakai, L. chinense, Liquidambar formosana, and Castanopsis sclerophylla (Lindl.) Schott. The dominant herb species in the planted pine forests include Saccharum arundinaceum, Imperata cylindrical (Linn.) Beauv., and Dicranopteris dichotoma, and those in the natural pine forests include I. cylindrical (Linn.) Beauv, Dryopteris fuscipes, and D. dichotoma.

\subsection{Aboveground and belowground biomass calculation}

The area of each plot was $1,000 \mathrm{~m}^{2}(20 \mathrm{~m} \times 50 \mathrm{~m})$. In October 2011, all plots were intensively surveyed, and the community structure, elevation, slope, forest age, and canopy density were recorded. The diameter at breast height $(\mathrm{DBH})$ of each tree
(DBH $\geq 5 \mathrm{~cm}$ at $1.3 \mathrm{~m}$ above ground) and height were recorded for all trees in each plot. We used the allometric growth equations for Masson's pine to quantify the total biomass and the biomass of the different plant components (e.g., stem, branch, leaf, and root) of each tree. To establish the equation, we selected and harvested 53 standard trees. The DBH of all standard trees ranged from $4.6 \mathrm{~cm}$ to $67.1 \mathrm{~cm}$ and their ages ranged from 4 years old to 115 years old. Analysis of covariance indicated that significant differences exist between the allometric growth equations of the planted and natural Masson's pines. Thus, the allometric growth equations of the planted and natural Masson's pines were established using 25 stems from the planted forests and 28 stems from the natural forests respectively (Table 2). We used the allometric growth equations of the planted and natural trees to estimate the aboveground biomass (stem, branch, and leaf) of each tree

Table 2 Allometric growth equations used to estimate biomass for planted and natural Masson's pine

\begin{tabular}{lllll}
\hline Organ & Management & Equation & $R^{2}$ & $P$ \\
\hline Stem & Planted & $0.025 \times\left(\mathrm{D}^{2} \mathrm{H}\right)^{0.957}$ & 0.963 & $<0.0001$ \\
& Natural & $0.031 \times\left(\mathrm{D}^{2} \mathrm{H}\right)^{0.931}$ & 0.992 & $<0.0001$ \\
\multirow{3}{*}{ Branch } & Planted & $0.062 \times\left(\mathrm{D}^{2} \mathrm{H}\right)^{0.696}$ & 0.865 & $<0.0001$ \\
& Natural & $0.024 \times\left(\mathrm{D}^{2} \mathrm{H}\right)^{0.755}$ & 0.818 & $<0.0001$ \\
Leaf & Planted & $0.103 \times\left(\mathrm{D}^{2} \mathrm{H}\right)^{0.508}$ & 0.811 & $<0.0001$ \\
& Natural & $0.142 \times\left(\mathrm{D}^{2} \mathrm{H}\right)^{0.374}$ & 0.732 & $<0.0001$ \\
\multirow{2}{*}{ Root } & Planted & $0.006 \times\left(\mathrm{D}^{2} \mathrm{H}\right)^{0.946}$ & 0.995 & $<0.0001$ \\
& Natural & $0.005 \times\left(\mathrm{D}^{2} \mathrm{H}\right)^{0.991}$ & 0.905 & $<0.0001$ \\
\hline
\end{tabular}

$\mathrm{D}$ and $\mathrm{H}$ are diameter at $1.3 \mathrm{~m}$ height $(\mathrm{cm})$ and tree height $(\mathrm{m})$ respectively 
and the total aboveground biomass for each plot in the planted and natural forests respectively.

Although few dead trees standing at $>45^{\circ}$ relative to the ground were found only in the mature natural pine forests, the standing dead trees were sampled within the entirety of each plot. The biomass of the intact standing dead trees was estimated using the above allometric growth equation. For broken standing dead trees, the top and bottom diameters of each piece were recorded, and their volume was estimated as the frustum of a cone (Fraver et al. 2007). The same decay classes and densities used for fallen coarse woody debris (CWD) were utilized for standing dead trees. The biomass of broken standing dead trees was calculated by multiplying their densities to their volume.

The biomass of coarse root $(\geq 2 \mathrm{~mm}$ ) was also calculated using the allometric growth equations (Table 2). The coarse root biomass of individual standard trees in the planted and natural forests was determined through excavation, where a cylinder extending from the ground projection of the crown at a depth of $60 \mathrm{~cm}$ was used to ascertain the data (Xiang et al. 2011). Soil was carefully excavated at a $20-\mathrm{cm}$-depth intervals and then sifted through a wire sieve (20-mm mesh), where roots were separated into bags. Stumps and attached taproots were pulled out. The soil residue remaining on the roots was removed by brushing and washing. All harvested roots were weighed and divided into four categories according to the method of Xiang et al. (2011). The subsamples of each category were brought to the laboratory and then dried at $65^{\circ} \mathrm{C}$ to constant weight. The moisture content was determined and used to calculate the dry mass of each category, and the total root biomass was achieved by combining the biomass of all categories.

The biomass of fine root $(<2 \mathrm{~mm})$ was measured using the soil coring method (Helmisaari et al. 2007). Ten soil cores were collected randomly from the $0-20$ and $20-40 \mathrm{~cm}$ mineral soil layers of each plot using a stainless steel cylinder with $10 \mathrm{~cm}$ diameter. The fine roots were separated from the soil by washing, and then dried at $65^{\circ} \mathrm{C}$ for 48 hours to calculate the dry biomass on an area basis. The density of fine root biomass (Goodfriend et al. 1998) was calculated from the mean dry biomass of the sampled fine root $\left(\mathrm{B}_{\mathrm{fr}}\right)$ and volume of the stainless steel cylinder (V) using the following equation: $\mathrm{D}_{\mathrm{fr}}$ $=\mathrm{B}_{\mathrm{fr}} / \mathrm{V}$. The total belowground biomass is equal to the sum of coarse root and fine root biomass.

We used the destructive harvesting method to estimate the biomass of the understory vegetation (herb and shrub). Three $2 \mathrm{~m} \times 2 \mathrm{~m}$ shrub subplots and one $1 \mathrm{~m} \times 1 \mathrm{~m}$ herb quadrat per subplot were randomly selected within each $20 \mathrm{~m} \times 50 \mathrm{~m}$ plot. In each shrub subplot, all harvested materials were separated into its component parts and then weighed to determine the fresh weight of stems, branches, and leaves. In each herb subplot, all herbs were clipped at ground line from each quadrat and were weighed to determine the fresh weight of the aboveground and belowground parts. Each component of shrub and herb was sampled, and each sample was placed into a separate plastic bag. The samples were transported to the laboratory and then dried at $65{ }^{\circ} \mathrm{C}$ to constant weight before biomass measurement.

\subsection{Debris biomass calculation}

In this study, debris included standing litter and CWD. Standing litter, which is the litter on the soil surface, was quantified by collecting all the litter and twigs $(<2 \mathrm{~cm}$ diameter) within a randomly selected $1 \mathrm{~m} \times 1 \mathrm{~m}$ subplot in each plot (similar to the herb quadrat). After sampling, all plant materials collected within these subplots were dried at $65{ }^{\circ} \mathrm{C}$ to constant weight prior to biomass measurement.

Given the human intervention, CWD ( $>2 \mathrm{~cm}$ diameter) occurred only in the mature stand of the natural Masson's pine forests. The amounts of CWD in the three $10 \mathrm{~m} \times 10 \mathrm{~m}$ subplots of mature stand in the natural forests were measured. The CWD biomass was calculated as the product of CWD volume and decay class-specific densities (Iwashita et al. 2013). Each piece of CWD was assigned to one of the five decay classes modified from Keller et al. (Keller et al. 2004). Decay classes 1-4 consist of successively more decomposed tree CWD, and the decay class 5 comprises tree fern CWD. The densities (dry mass/volume) of each decay class were quantified on representative samples from crosssections of debris collected in situ from random locations using the water displacement method, except for decay class 1 , which was based on live wood density.

\subsection{Soil sampling}

Soil sampling was conducted in five soil layers, namely, 0-10, 10-20, 20-30, 30-50, and 50-100 cm, using a stainless steel cylinder with $5 \mathrm{~cm}$ diameter. In each $20 \mathrm{~m} \times 50 \mathrm{~m}$ plot, eight soil cores were collected after removing the litter layer and then mixed to effectively form one soil sample. All samples were passed through a $2-\mathrm{mm}$ sieve to remove the organic fragments (plant material and root residues). Each sample was then air-dried and stored at room temperature for chemical analysis. The soil bulk density of the different soil layers was also measured, using a soil bulk sampler with a $5 \mathrm{~cm}$ diameter and a $5.0 \mathrm{~cm}$ high stainless steel cutting ring (three replicates) in each plot. The original volumes of each soil core and its dry mass after drying at $105{ }^{\circ} \mathrm{C}$ were measured. The coarse fractions (soil fraction $>2 \mathrm{~mm}$ ) of each sample were also recorded.

\subsection{Chemical analysis}

All plant materials, including the components of tree species (stem, branch, leaf, and coarse and fine roots), shrub (stem, 
branch, and leaf), herb (aboveground and belowground), litter, and CWD of the different decay classes, were dried at $65^{\circ} \mathrm{C}$ for two days and then ground to $0.25 \mathrm{~mm}$ before chemical analysis of organic carbon content. The soil samples were air-dried at room temperature for 1 week and then ground to $0.25 \mathrm{~mm}$ before chemical analysis. The carbon concentrations of the plant and soil samples were measured using a $\mathrm{C} / \mathrm{N}$ analyzer (Elementar, Germany).

\subsection{Calculation and statistical analysis}

The carbon stocks in the tree, shrub, herb, and woody debris were estimated by multiplying their measured biomass to their corresponding carbon concentrations. The soil carbon stock density $\left(\mathrm{Cs}, \mathrm{Mg} \mathrm{ha}^{-1}\right)$ in each soil layer was calculated based on soil organic carbon concentration $\left(\mathrm{Cc}, \mathrm{g} \mathrm{kg}^{-1}\right)$, sampled depth $(\mathrm{D}, \mathrm{cm})$, and bulk density (BD, $\mathrm{g} \mathrm{cm}^{-3}$ ) using the following equation: $\mathrm{Cs}=\mathrm{BD} \times \mathrm{D} \times \mathrm{Cc} / 10$. The total soil carbon stock density was the sum of the carbon stock of each soil layer.

The characteristics of the Masson's pine forests, such as age, slope, elevation, canopy closure, DBH, tree height, stand density, plant biomass, and debris and soil carbon stock densities and their proportions in the planted and natural forests were compared through ANOVA using SPSS Statistics Release 15.0 (SPSS Inc.). Tukey's honestly significant difference test was performed as a post-hoc test to separate the means when significant differences exist. Significance levels were set at $p<0.05$ in all statistical analyses.

\section{Results}

\subsection{Biomass carbon stock density}

The carbon stock densities of the tree layer of the planted and natural Masson's pine forests were significantly different $(p<0.05$, Fig. 2). The carbon stock density in the tree layer at middle-aged and mature ages of the planted pine forests was greater than that in the natural pine forests. In addition, the carbon stock densities of the tree in pine forests increased gradually and differed significantly as the forests developed. Significant interactions in the carbon stock density of the tree layer also exist between stand management and age, as shown by two-way ANOVA. At young age, the carbon stock densities in the tree layer did not differ between the planted $\left(13.88 \mathrm{Mg} \mathrm{ha}^{-1}\right)$ and the natural forests $\left(12.08 \mathrm{Mg} \mathrm{ha}^{-1}\right)$. However, significant differences exist between the carbon stock densities in the tree layer of the planted (61.52 and $137.43 \mathrm{Mg} \mathrm{ha}^{-1}$ ) and natural forests (40.08 and $76.71 \mathrm{Mg} \mathrm{ha}^{-1}$ ) at middle-aged and mature ages. Moreover, the proportion of carbon stock densities were significantly higher in the tree layer of the planted pine forests $(64.70 \%)$
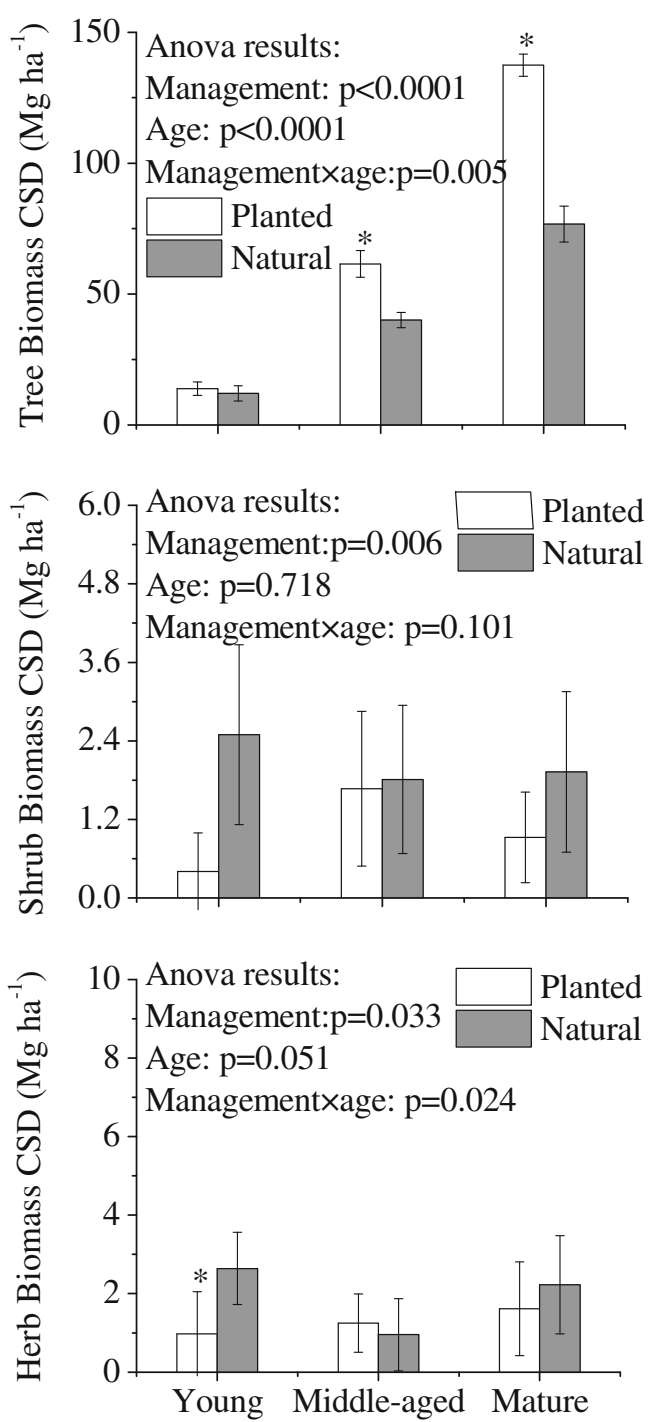

Fig. 2 Plant biomass carbon stock density of planted and natural Pinus massoniana forests in Hunan Province, China. CSD is the abbreviation of carbon stock density. Asterisk on bars denotes significant difference between planted and natural forests at the same age at $p=0.05$ based on one-way ANOVA

than in the natural pine forests $(41.12 \%)$ at mature age. However, no differences were observed between the planted and natural pine forests at young and middle-aged ages $(p<0.05$, Table 3$)$.

The carbon stock densities in the shrub and herb layers were significantly lower in the planted pine forests than in the natural pine forests ( $p<0.05$, Fig. 2). This trend was opposite to that of the tree layer. Moreover, no significant differences in the carbon stock densities in the shrub and herb layers of the pine forests were observed at different ages. Twoway ANOVA revealed the significant interactions between stand management and age in terms of carbon stock density in the herb layer. At a young age, the carbon stock density was significantly lower in the herb layer of the planted pine forests 
Table 3 The proportions of carbon stock densities of planted and natural Pinus massoniana forests in Hunan Province, China

\begin{tabular}{|c|c|c|c|c|c|c|}
\hline \multirow[t]{2}{*}{ Component } & \multicolumn{2}{|l|}{ Young forest } & \multicolumn{2}{|c|}{ Middle-aged forest } & \multicolumn{2}{|l|}{ Mature forest } \\
\hline & Planted(\%) & Natural(\%) & Planted(\%) & Natural(\%) & Planted(\%) & Natural(\%) \\
\hline Tree & $17.74 \pm 2.66$ & $10.90 \pm 1.70$ & $42.65 \pm 6.54$ & $33.35 \pm 3.80$ & $64.70 \pm 3.08^{* *}$ & $41.12 \pm 3.89$ \\
\hline Shrub & $0.64 \pm 0.20$ & $1.67 \pm 0.63$ & $1.17 \pm 0.48$ & $1.51 \pm 0.31$ & $0.43 \pm 0.09^{*}$ & $1.14 \pm 0.21$ \\
\hline Herb & $1.93 \pm 0.87$ & $3.26 \pm 0.96$ & $0.90 \pm 0.16$ & $0.76 \pm 0.14$ & $0.76 \pm 0.29$ & $1.34 \pm 0.29$ \\
\hline Debris & $2.35 \pm 0.46$ & $3.11 \pm 0.92$ & $1.94 \pm 0.31$ & $2.62 \pm 0.37$ & $1.34 \pm 0.17$ & $2.47 \pm 0.43$ \\
\hline Soil & $77.50 \pm 2.47$ & $81.06 \pm 2.06$ & $53.34 \pm 6.07$ & $61.75 \pm 4.00$ & $32.77 \pm 3.22 * *$ & $53.93 \pm 3.39$ \\
\hline
\end{tabular}

Data are means followed by standard deviations. For each compartment, values with asterisks denote significant difference between planted and natural pine forests at the same age at $p<0.05$ based on one-way ANOVA $\left(0.98 \mathrm{Mg} \mathrm{ha}^{-1}\right)$ than in the natural pine forests $\left(2.64 \mathrm{Mg} \mathrm{ha}^{-1}\right)$, although the carbon stock density did not vary between the planted (1.25 and 1.61 $\left.\mathrm{Mg} \mathrm{ha}^{-1}\right)$ and natural pine forests $(0.95$ and $2.22 \mathrm{Mg} \mathrm{ha}^{-1}$ ) at middle-aged and mature ages. In addition, the proportion of carbon stock density was significantly lower in the shrub layer of the planted pine forests $(0.43 \%)$ than in the natural pine forests $(1.14 \%)$ at mature age, and no difference was observed between the planted and natural forests at young and middle-aged ages $(p<0.05$, Table 3$)$. No significant difference in the proportions of carbon stock density in the herb layer was also observed between the planted and natural pine forests at all ages.

The carbon stock densities were significantly higher in the vegetation of the planted Masson's pine forests than in the natural pine forests $(p<0.05$, Fig. 3). Significant differences among the carbon stock densities in the vegetation of pine forests in different ages were also observed, as follows: mature $>$ middle-aged $>$ young. Two-way ANOVA showed that significant interactions in carbon stock density in the vegetation exist between stand management and age. Although no significant difference was observed between the carbon stock densities of the vegetation in the planted $\left(15.10 \mathrm{Mg} \mathrm{ha}^{-1}\right)$ and natural forests $\left(16.50 \mathrm{Mg} \mathrm{ha}^{-1}\right)$ at young age, the carbon stock densities were significantly greater in the vegetation of the planted pine forests (64.26 and $139.98 \mathrm{Mg} \mathrm{ha}^{-1}$ ) than in the natural pine forests (42.84 and $80.86 \mathrm{Mg} \mathrm{ha}^{-1}$ ) at middleaged and mature ages.

\subsection{Debrisand soil carbon stock density}

Debris is defined as the dead material found in the forest floor, and is equal to the sum of litter and CWD. The carbon stock densities were significantly lower in the debris found in the planted Masson's pine forests than in the natural pine forests $(p<0.05$, Fig. 3). No significant difference was also observed between the soil carbon stock densities across all depths of the planted and natural pine forests ( $p<0.05$, Fig. 3 ). In addition, the soil carbon stock densities in the pine forests did not vary as the forests developed. The proportion of soil carbon stock density was significantly lower in the planted forests $(32.77 \%)$ than in natural forests $(53.93 \%)$ at mature age, but the proportions of soil carbon stock density in the planted forests at young and middle-aged ages did not differ with those in the natural forests at corresponding ages.
Fig. 3 Ecosystem carbon stock density of planted and natural Pinus massoniana forests in Hunan Province, China. CSD is the abbreviation of carbon stock density. Asterisk on bars denotes significant difference between planted and natural forests at the same age at $p=0.05$ based on one-way ANOVA
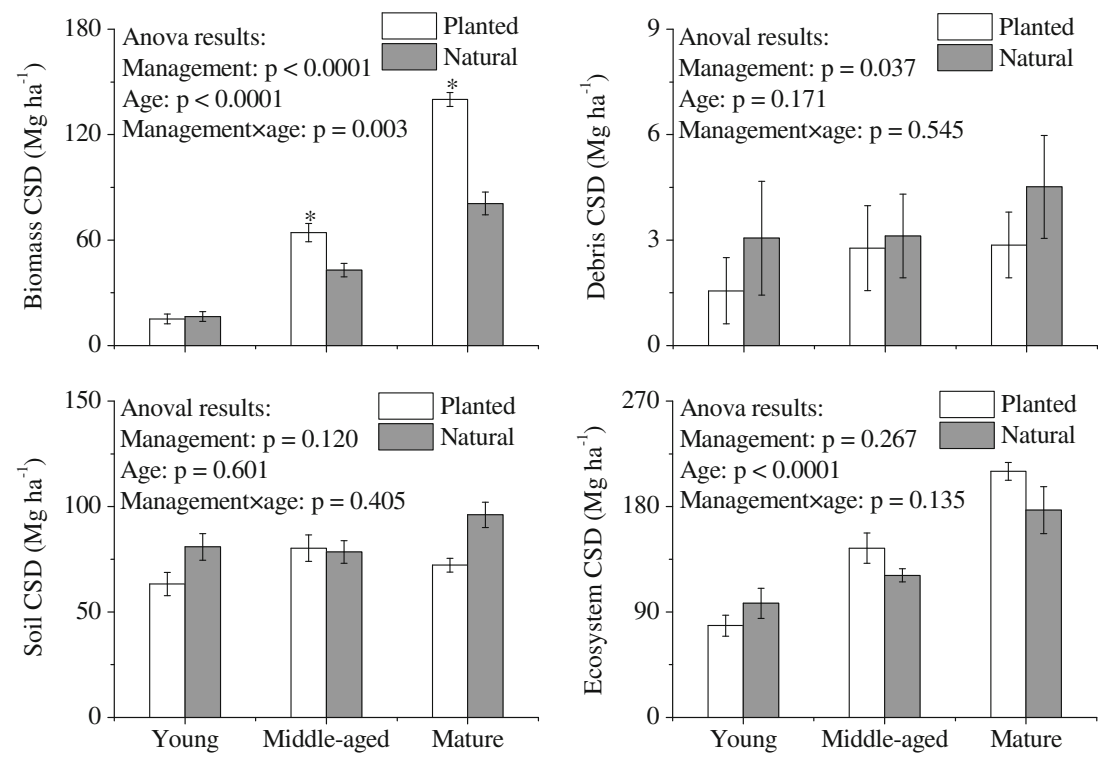


\subsection{Carbon stock density in forest ecosystem}

The carbon stock densities of the planted and natural pine forest ecosystems are not significantly different $(p<0.05$, Fig. 3). Moreover, the carbon stock densities in the planted and natural pine forest ecosystems increased gradually and then differed significantly as the forests developed.

\section{Discussion}

\subsection{Biomass carbon stock density}

Vegetation is a very important carbon pool in forests (Fang et al. 2005). The carbon stock density in the vegetation of the planted Masson's pine forests increased from $15.1 \mathrm{Mg} \mathrm{ha}^{-1}$ to 140.0 $\mathrm{Mg} \mathrm{ha}^{-1}$ as the forests developed. These values are found within the range of biomass carbon stock density (8.4-145.7 $\mathrm{Mg} \mathrm{ha}^{-1}$ ) reported for the Masson's pine forests in China (Huang et al. 2008, 2013; Wu et al. 2012). By contrast, the biomass carbon stock density in the natural Masson's pine forests ranged from $16.5 \mathrm{Mg} \mathrm{ha}^{-1}$ to $80.9 \mathrm{Mg} \mathrm{ha}^{-1}$, which exceeded the range of the biomass carbon stock density (20.464.4 $\mathrm{Mg} \mathrm{ha}^{-1}$ ) reported for the natural pine forests in Hubei Province (Pang et al. 2014). The biomass carbon stock density were significantly greater in the planted than in natural pine forests, especially in mature age. The changes of carbon stock densities in the vegetation of planted forests at young and middle-aged ages compared to mature age were 124.88 and $75.72 \mathrm{Mg} \mathrm{ha}^{-1}$, and they were much larger than that of natural forests $\left(64.36 \mathrm{Mg} \mathrm{ha}^{-1}\right.$ for young and $38.02 \mathrm{Mg} \mathrm{ha}^{-1}$ for midle-aged). This result is consistent with that obtained by Guo and Ren (2014), who suggested that planted forests exihibit much higher productivity and thus much higher carbon sequestration rates than natural forests. Huang et al. (2008) also found that the annual increment of carbon stocks is much greater in planted forests than that in natural forests in Sichuan Province in China. The differences in the biomass carbon stock density of the planted and natural pine forests were due to several reasons. First, the allelometric growth equations for the planted and natural Masson's pine varied (Table 2). Being the most important component of vegetation, the tree biomass exerts much influence on the carbon stock density in the vegetation. Typically, we used each allelometric growth equation for planted and natural Masson's pine; tree biomass of planted pine was more than that of natural pine. For example, if the DBH and height of a pine tree are $15.3 \mathrm{~cm}$ and $11 \mathrm{~m}$, by using each equation, the tree biomass of the planted and natural pine are 76.3 and $70.1 \mathrm{~kg}$ respectively. Second, the management intensity in the planted and natural pine forests varied. Management practices (higher intervention intensity) are usually implemented in the planted pine forests; however, lower intensity of human intervention, such as fire wood collection and grazing by cattles, is practised in the natural pine forests. Increased management intensity has been shown to enhance the yield and carbon storage of biomass (Wade et al. 2010). In subtropical China, the understory plants in the planted pine forest at young age are usually removed to improve the pine tree's survival rate. Understory removal affects tree growth and increases carbon stock density in the vegetation (Wu et al. 2013). Thinning and fertilization regimes are also common management practices. Thinning regimes increase the carbon stock density in total aboveground biomass (Finkral and Evans 2008; Garcia-Gonzalo et al. 2007). Because thinning is a usual management practice, the stand densities of the planted pine forests decrease significantly as the forests develop. However, our study found that the stand densities of the natural forests did not change as the forests developed (Table 1). Fertilization also increases the net primary productivity and net ecosystem productivity (Sampson et al. 2006). However, in this study, soil total nitrogen of planted pine forests was similiar to that of natural forests, and the difference in soil total phosphorus was only found in planted and natural forests at young age, but not at other ages. It indicated that soil fertility was not the cause of difference in carbon stock densities in the vegetation between planted and natural pine forests. Thus, management practices, such as understory control and thinning, resulted in an increase in forest productivity and timber product in Hunan Province and enhanced the biomass carbon stock density in the planted forests. These data indicate that more atmospheric carbon are sequestered in the vegetation biomass carbon of the the planted pine forest than of the natural pine forest.

Stand age is one of the factors that controls forest ecosystem biomass and is commonly positively related to biomass carbon stock density of forest ecosystems (Du et al. 2013; Guo and Ren 2014). Stand age can explain the significantly increased carbon stock density in the vegetation of the planted and natural pine forests as the forests develop. Being the most important component of vegetation, the tree biomass increases significantly with the increase in stand age, resulting in the increase in carbon stock density in the vegetation as the forests develop. This study found significant interactions between stand management and age in terms of tree and carbon stock density in the vegetation. The carbon stock densities of the trees and other forms of vegetation in the planted and natural forests did not differ at young age, although they were significantly greater in the planted forests than in natural forests at later ages, especially at mature age. This difference was also caused by the differences in the allelometric growth equation of the planted and natural Masson's pine trees. The results indicated that prolonged rotation time of pine plantation is beneficial in sequestering carbon and in mitigating global climate change.

Although the tree biomass contributed the largest proportion of vegetation biomass in these forests, the shrub and herb 
biomass also accounted for 0.6-13.2\% and 1.1-23.2\% respectively. This study also found low contribution of understory biomass, although it comprises one-third of the total vegetation biomass at young age. Du et al. (2013) reported that biomass of the understory is approximately five times that of the tree in the planted Masson's pine forest at 5 years old. Thus, the shrub and herb components can not be ignored when estimating carbon stocks in Masson's pine forests, especially at young age. Significant differences were also observed in the interaction between stand management and age in terms of carbon stock density in the herb layer. In addition, the carbon stock density in the herb layer was significantly lower in the planted forests than in the natural forests at young age, but did not differ at middle-aged and mature ages. This result is caused by removal of the understory in the planted forests at young age. However, Wu et al. (2013) reported that understory removal increases carbon stock density in the vegetation. Thus, the trade-off of understory removal on herb and carbon stock densities in the vegetation of forest ecosystems is very important in carbon sequestration.

\subsection{Carbon stock density in the debris}

Litter (or debris) is an important source of the soil carbon pool (Osono et al. 2014) and affects the soil carbon stock density (Muller et al. 2009). The carbon stock densities in the debris in the planted Masson's pine forests ranged from 1.6 $\mathrm{Mg} \mathrm{ha}^{-1}$ to $2.9 \mathrm{Mg} \mathrm{ha}^{-1}$ and were significantly lower than those in the natural pine forests $\left(3.0 \mathrm{Mg} \mathrm{ha}^{-1}\right.$ to $\left.4.5 \mathrm{Mg} \mathrm{ha}^{-1}\right)$. The changes of carbon stock densities in the debris of planted forests at young and middle-aged ages compared to mature age were 1.30 and $0.09 \mathrm{Mg} \mathrm{ha}^{-1}$ respectively, and were less than that of natural forests, which were 1.47 and $1.40 \mathrm{Mg} \mathrm{ha}^{-1}$. This finding is consistent with the results of Du et al. (2013) and Pang et al. (2014). The litter carbon stock in planted pine forests reported by $\mathrm{Du}$ et al. (2013) ranges from $1.6 \mathrm{Mg} \mathrm{ha}^{-1}$ to 3.0 $\mathrm{Mg} \mathrm{ha}^{-1}$ and is lower than that reported by Pang et al. (2014), who found that litter carbon stock density in natural pine forests ranged from $1.7 \mathrm{Mg} \mathrm{ha}^{-1}$ to $4.2 \mathrm{Mg} \mathrm{ha}^{-1}$. This finding may be attributed to the management treatments implemented in the planted forests and to the absence of human intervention in the natural forests. Reforestation following clear-cutting and slash-burning is a traditional silvicultural practice in South China (Guo et al. 2006). The debris on stand floor is transformed mostly into $\mathrm{CO}_{2}$, and is released into the atmosphere following slash-burning. Approximately $10 \mathrm{Mg} \mathrm{ha}^{-1}$ carbon in debris (harvest residues) is directly lost in volatile forms resulting from burning (Yang et al. 2005), thereby reducing the carbon stock density in the debris in planted pine forests. In addition, litter management in planted pine forests also affects the carbon stock density in the debris. Debris are usually collected and used as burning material, resulting in reduced carbon stock density in the debris in planted pine forests.

\subsection{Soil carbon stock density}

Globally, over two-thirds of the carbon pools in forest ecosystems are contained in soil (Dixon et al. 1994). This study found that the carbon pools stored in soils across all depths accounted for $32.8-77.5 \%$ and $53.9-81.1 \%$ of the carbon pools in the planted and natural pine forest ecosystems respectively. This finding is consistent with the results of Pang et al. (2014), who found that 55.1-65.6\% of forest ecosystem carbon is stored in soil. Although soil carbon stock densities in pine forests tended to increase as forests developed, they did not differ in the pine forests at young, middle-aged, and mature ages, possibly because the slight changes in soil carbon stock density did not affect the overall soil carbon pool. These data indicated that the soil carbon pool is relatively stable and does not readily change within a short term. Compared with that of the soil carbon pool, the role of vegetation biomass carbon pool in mitigating global climate change is stronger because the carbon stock density in the vegetation changes significantly as the forests develop.

Although the soil carbon stock densities in the planted and natural pine forests did not differ, that in the planted pine forests tended to decrease compared with that in the natural forests. The changes of soil carbon stock densities of planted pine forests at young and middle-aged ages compared to mature age were 8.96 and $-8.03 \mathrm{Mg} \mathrm{ha}^{-1}$, and were less than those of natural forests, which were 15.25 and $17.68 \mathrm{Mg} \mathrm{ha}^{-1}$. This indicated that there was a larger carbon sequestration potential in soil of natural pine forests compared to planted forests. Land-use history is possibly one of the factors causing the difference in soil carbon stock densities between the planted and natural pine forests. In this study, the planted pine forests were all established after clearcutting and slash-burning of the existing Chinese fir plantations, whereas the natural pine forests were established naturally. Afforestation of the Chinese fir plantation has been shown to decrease soil carbon stock density compared with the natural broadleaved forest (Chen et al. 2013). Moreover, Yang et al. (2005) reported that approximately $7 \mathrm{Mg} \mathrm{ha}^{-1}$ of topsoil carbon is lost by the slash-burning of Chinese fir plantations. In Australia, soil carbon loss in radiata pine plantations after burning is estimated to be $2.4 \mathrm{Mg} \mathrm{ha}^{-1}$ (Turner and Lambert 2000). Thus, afforesting pine forests in Chinese fir plantations after slash-burning may result in soil carbon loss. In addition, management practices, such tree thinning and slash-burning, which are implemented in planted pine forests exert different effects on soil carbon. Studies have reported that management practices such as prescribed fire, mechanical treatment, and thinning do not affect soil carbon stock density (Boerner et al. 2008; Liang et al. 2013; Nilsen and Strand 
2008). However, other studies have reported that management practices do affect soil carbon stock density of planted forests (Tian et al. 2010; Wu et al. 2013). Thinning regimes increases soil carbon storage in Masson's pine forests (Tian et al. 2010). Wu et al. (2013) suggested that understory removal decreases soil carbon storage in Cinnamomum camphora forests. This finding is attributed to several reasons. First, the manner by which these management practices, such as thinning, understory removal, slash-burning, and fertilization, were implemented varies. Thus, they exert different effects on soil carbon stock density. Second, the degree of implementation of these management practices varies. Thinning intensity slightly affects the carbon stock in red pine, whereas increasing the management intensity greatly reduces carbon stock in northern hardwoods (Powers et al. 2011). Lastly, the tree species vary. For example, thinning reduces the carbon stock density in aboveground biomass in P. ponderosa forest (Finkral and Evans 2008), but increases the carbon stock density in P. sylvestris and P. abies forests (Garcia-Gonzalo et al. 2007).

Overall, more carbon is sequestered in the carbon biomass of the planted Masson's pine forests than that of the natural pine forests. However, no significant difference exists between the carbon stock density of the two pine forest ecosystems, because of the decrease of carbon stock densities in soil and debris of planted forests compared to natural forests. Selecting and optimizing the forest management practices in plantations will increase soil carbon stock density in the planted forest, which is a very important process in carbon sequestration and global climate change mitigation. The potential of the Masson's pine forests in Hunan Province, China, to sequester carbon is enormous given the growing area of the planted forests and the changes in carbon uptake with stand development. Moreover, selecting the appropriate management practices can help achieve this goal.

\section{Conclusion}

The carbon stock densities in the planted and natural Masson's pine forest ecosystems ranged from $78 \mathrm{Mg} \mathrm{ha}^{-1}$ to $210 \mathrm{Mg} \mathrm{ha}^{-1}$ and from $97 \mathrm{Mg} \mathrm{ha}^{-1}$ to $177 \mathrm{Mg} \mathrm{ha}^{-1}$ respectively, of which $15-140$ and $17-81 \mathrm{Mg} \mathrm{ha}^{-1}$ biomass values are the carbon stock densities in the planted and natural forests respectively. In addition, the biomass carbon stock densities were much greater in the planted pine forests than in the natural pine forests. By contrast, the carbon stock densities in the debris were lower in the planted forests than in the natural forests. However, the soil carbon stock densities in the planted and natural pine forests did not differ, although a decrease trend of soil carbon stock densities appeared in planted forests compared to natural forests. The decrease of carbon stock densities in the debris and soil of planted forests compared to natural forests counteracted the increase of biomass carbon stock densities, and resulted in no difference in carbon stock densities between planted and natural forests at ecosystem level. The biomass carbon stock densities of pine forests increased significantly as the forests developed, although no change was observed in the debris and soil carbon stock densities. These results indicate that the potential of the mature Masson's pine forests to sequester carbon is enormous. Moreover, the planted forests can sequester more biomass carbon than the natural forests. The key is to understand and optimize forest management practices aimed at increasing forest carbon sinks.

Acknowledgments We gratefully acknowledge Shi-Jian Deng, Bing Fan, Wei-Dong Zhang, and Hai-Jun Yang for their valuable assistance in the field survey. We are grateful to the assistance of Professor Emeritus John A. Helms, College of Natural Resources, University of California, Berkeley, for his valuable comments. We greatly appreciate the comments of the reviewers and the editor, which have substantially enhanced the quality of the manuscript.

\section{Compliance with ethical standards}

Funding This study was supported by the Strategic Priority Research Program of the Chinese Academy of Sciences (XDA05050205) and the National Basic Research Program of China (973 program no. 2012CB416905).

\section{References}

Boerner REJ, Huang JJ, Hart SC (2008) Fire, thinning, and the carbon economy: effects of fire and fire surrogate treatments on estimated carbon storage and sequestration rate. For Ecol Manag 255:30813097. doi:10.1016/j.foreco.2007.11.021

Chen GS, Yang YS, Xie JS, Guo JF, Gao R, Qian W (2005) Conversion of a natural broad-leafed evergreen forest into pure plantation forests in a subtropical area: effects on carbon storage. Ann For Sci 62:659 668. doi:10.1051/forest.2005073

Chen GS, Yang ZJ, Gao R, Xie JS, Guo JF, Huang ZQ, Yang YS (2013) Carbon storage in a chronosequence of Chinese fir plantations in southern China. For Ecol Manag 300:68-76. doi:10.1016/j.foreco. 2012.07.046

Del Lungo A, Ball J, Carle J (2006) Global planted forests thematic study: results and analysis. FAO Planted Forests and Trees Working Paper 38. FAO, Rome

Ding GJ, Wang PC (2001) Study on change laws of biomass and productivity of Masson pine forest plantation. Biomass and productivity of stand ar different ages. For Res Sin 15:54-60

Dixon RK, Brown S, Houghton RA, Solomon AM, Trexler MC, Wisniewski J (1994) Carbon pools and flux of global forest ecosystems. Science 263:185-190

Du H, Song TQ, Zeng FP, Wen YG, Peng WX (2013) Biomass and its allocation in Pinus Massoniana plantation at different stands ages in east Guangxi. Acta Bot Bor Occid Sin 33:394-400

Fang JY, Oikawa T, Kato T, Mo WH, Wang ZH (2005) Biomass carbon accumulation by Japan's forests from 1947 to 1995 . Glob Biogeochem Cycles 19:Gb2004. doi:10.1029/2004gb002253

Fang HJ, Yu GR, Cheng SL, Zhu TH, Zheng JJ, Mo JM, Yan JH, Luo YQ (2011) Nitrogen-15 signals of leaf-litter-soil continuum as a possible 
indicator of ecosystem nitrogen saturation by forest succession and $\mathrm{N}$ loads. Biogeochemistry 102:251-263. doi:10.1007/s10533-0109438-1

Food and Agricultural Organization of the United Nations (2010) Global forest resources assessment 2010. FAO, Rome

Finkral AJ, Evans AM (2008) Effects of a thinning treatment on carbon stocks in a northern Arizona ponderosa pine forest. For Ecol Manag 255:2743-2750. doi:10.1016/j.foreco.2008.01.041

Forestry Department of Hunan Province PRC (2010) Hunan province forest inventory database. Forestry Department of Hunan Province, China

Fraver S, Ringvall A, Jonsson GB (2007) Refining volume estimates of down woody debris. Can J For Res 37:627-633

Garcia-Gonzalo J, Peltola H, Briceno-Elizondo E, Kellomaki S (2007) Changed thinning regimes may increase carbon stock under climate change: a case study from a Finnish boreal forest. Clim Chang 81: 431-454. doi:10.1007/s10584-006-9149-8

Goodfriend WL, Olsen MW, Frye RJ (1998) Decomposition of seawaterirrigated halophytes: implications for potential carbon storage. Plant Soil 202:241-250. doi:10.1023/a:1004360422347

Guo Q, Ren H (2014) Productivity as related to diversity and age in planted versus natural forests. Glob Ecol Biogeogr 23:1461-1471. doi:10.1111/geb.12238

Guo JF, Yang YS, Chen GS, Xie JS, Lin P (2006) Soil C and N pools in Chinese fir and evergreen broadleaf forests and their changes with slash burning in mid-subtropical China. Pedosphere 16: $56-63$

Helmisaari HS, Derome J, Nojd P, Kukkola M (2007) Fine root biomass in relation to site and stand characteristics in Norway spruce and Scots pine stands. Tree Physiol 27:1493-1504

Huang CD, Zhang J, Yang WQ, Tang X, Zhao AJ (2008) Dynamics of forest carbon stock in Sichuan province and Chongqing city. Acta Ecol Sin 28:966-975

Huang SL, Xu HQ, Lin N, Zeng HD, Liu ZC, Chen WH, Wang L, Yang RR (2013) Remote-sensing estimate of the carbon storage of subtropical Pinus massoniana forest in the Hetian Basin of county Changting, China. Acta Ecol Sin 33:2992-3001

Iwashita DK, Litton CM, Giardina CP (2013) Coarse woody debris carbon storage across a mean annual temperature gradient in tropical montane wet forest. For Ecol Manag 291:336-343. doi:10.1016/j. foreco.2012.11.043

Jandl R, Lindner M, Vesterdal L, Bauwens B, Baritz R, Hagedorn F, Johnson DW, Minkkinen K, Byrne KA (2007) How strongly can forest management influence soil carbon sequestration? Geoderma 137:253-268. doi:10.1016/j.geoderma.2006.09.003

Keller M, Palace M, Asner GP, Pereira R, Silva JNM (2004) Coarse woody debris in undisturbed and logged forests in the eastern Brazilian Amazon. Glob Chang Biol 10:784-795. doi:10.1111/j. 1529-8817.2003.00770.x

Laganière J, Angers DA, Paré D (2010) Carbon accumulation in agricultural soils after afforestation: a meta-analysis. Glob Chang Biola 16: 439-453. doi:10.1111/j.1365-2486.2009.01930.x

Li DJ, Niu SL, Luo YQ (2012) Global patterns of the dynamics of soil carbon and nitrogen stocks following afforestation: a meta-analysis. New Phytol 195:172-181. doi:10.1111/j.1469-8137.2012.04150.x

Liang F, Jia ZK, Ma LY (2013) The effects of thinning on carbon stocks and fluxes in a Chinese arborvitae plantation. For Chron 89:199204. doi:10.5558/tfc2013-038

Liao CZ, Luo YQ, Fang CM, Li B (2010) Ecosystem carbon stock influenced by plantation practice: implications for planting forests as a measure of climate change mitigation. Plos One 5:e10867. doi:10. 1371/journal.pone.0010867

Liu Q (1996) Studies of the biomass and productivity of different age-group Pinus massoniana plantation. J Centr South For Univ 16:47-51
Liu J, Li S, Ouyang Z, Tam C, Chen X (2008) Ecological and socioeconomic effects of China's policies for ecosystem services. PNAS 105: 9477-9482. doi:10.1073/pnas.0706436105

Mo JM, Brown S, Kong GH, Zhang YC, Lenart M (1999) Nutrient distribution and cycling of a Masson's pine planted forest in Dinghushan. Acta Ecol Sin 19:635-640

Muller M, Alewell C, Hagedorn F (2009) Effective retention of litterderived dissolved organic carbon in organic layers. Soil Biol Biochem 41:1066-1074. doi:10.1016/j.soilbio.2009.02.007

Nilsen P, Strand LT (2008) Thinning intensity effects on carbon and nitrogen stores and fluxes in a Norway spruce (Picea abies (L.) Karst.) stand after 33 years. For Ecol Manag 256:201-208. doi:10. 1016/j.foreco.2008.04.001

Niu X, Duiker SW (2006) Carbon sequestration potential by afforestation of marginal agricultural land in the Midwestern U.S. For Ecol Manag 223:415-427. doi:10.1016/j.foreco.2005.12.044

Osono T, Azuma J, Hirose D (2014) Plant species effect on the decomposition and chemical changes of leaf litter in grassland and pine and oak forest soils. Plant Soil 376:411-421

Pang H, Wang X, Zhang J, Zheng L, Cui H (2014) Characteristics of carbon storage and carbon density of Pinus massoniana natural forests in Hubei Province, China. J Northeast For Univ 42:40-43

Perez-Quezada JF, Delpiano CA, Snyder KA, Johnson DA, Franck N (2011) Carbon pools in an arid shrubland in Chile under natural and afforested conditions. J Arid Environ 75:29-37. doi:10.1016/j. jaridenv.2010.08.003

Powers M, Kolka R, Palik B, McDonald R, Jurgensen M (2011) Longterm management impacts on carbon storage in Lake States forests. For Ecol Manag 262:424-431. doi:10.1016/j.foreco.2011.04.008

Sampson DA, Waring RH, Maier CA, Gough CM, Ducey MJ, Johnsen KH (2006) Fertilization effects on forest carbon storage and exchange, and net primary production: a new hybrid process model tor stand management. For Ecol Manag 221:91-109. doi:10.1016/j. foreco.2005.09.010

State Forestry Administration PRC (2009) The bulletin of China's forest resource: the Seventh National Forest Resources Inventory. China Forestry Press, Beijing

Tang GY, Li K (2013) Tree species controls on soil carbon sequestration and carbon stability following 20 years of afforestation in a valleytype savanna. For Ecol Manag 291:13-19. doi:10.1016/j.foreco. 2012.12.001

Thornley JHM, Cannell MGR (2000) Managing forests for wood yield and carbon storage: a theoretical study. Tree Physiol 20:477-484

Tian DL, Peng YY, Yan WD, Fang X, Kang WX, Wang GJ, Chen XY (2010) Effects of thinning and litter fall removal on fine root production and soil organic carbon content in Masson pine plantations. Pedosphere 20:486-493

Turner J, Lambert M (2000) Change in organic carbon in forest plantation soils in eastern Australia. For Ecol Manag 133:231-247

Vesterdal L, Rosenqvist L, van der Salm C, Groenenberg B-J, Johansson M-B, Hansen K (2006) Carbon sequestration in soil and biomass following afforestation: experiences from oak and Norway spruce chronosequences in Denmark, Sweden, and the Netherlands. In: Heil G, Muys B, Hansen K (eds) Environmental effects of afforestation in North-Western Europe from field observations to decision support. Springer, Berlin, pp 19-51

Wade ASI, Asase A, Hadley P, Mason J, Ofori-Frimpong K, Preece D, Spring N, Norris K (2010) Management strategies for maximizing carbon storage and tree species diversity in cocoa-growing landscapes. Agric Ecosyst Environ 138:324-334. doi:10.1016/j.agee. 2010.06.007

Wang QK, Wang SL, Zhong MC (2013) Ecosystem carbon storage and soil organic carbon stability in pure and mixed stands of Cunninghamia lanceolata and Michelia macclurei. Plant Soil 370: 295-304. doi:10.1007/s11104-013-1631-2 
Winjum JK, Schroeder PE (1997) Forest plantations of the world: their extent, ecological attributes, and carbon storage. Agric For Meteorol 84:153-167. doi:10.1016/s0168-1923(96)02383-0

Wu T, Peng C, Tian DL, Yan WD (2012) Spatial distribution of carbon storage in a 13-year-old Pinus massoniana forest ecosystem in Changsha City, China. Acta Ecol Sin 32:4034-4042

Wu Y-C, Li Z-C, Cheng C-F, Liu R-J, Wang B, Geri L-T (2013) Effects of understory removal on forest carbon storage in Cinnamomum camphora plantation ecosystem. Chin J Plant Ecol 37:142-149. doi:10.3724/sp.j.1258.2013.00015

Xiang WH, Liu SH, Deng XW, Shen AH, Lei XD, Tian DL, Zhao MF, Peng CH (2011) General allometric equations and biomass allocation of Pinus massoniana trees on a regional scale in southern China. Ecol Res 26:697-711

Yan JH, Zhang DQ, Zhou GY, Liu JX (2009) Soil respiration associated with forest succession in subtropical forests in Dinghushan
Biosphere Reserve. Soil Biol Biochem 41:991-999. doi:10.1016/j. soilbio.2008.12.018

Yang YS, Guo J, Chen G, Xie J, Gao R, Li Z, Jin Z (2005) Carbon and nitrogen pools in Chinese fir and evergreen broadleaved forests and changes associated with felling and burning in mid-subtropical China. For Ecol Manag 216:216-226. doi:10.1016/j.foreco.2005. 05.030

Yang HX, Wang SL, Zhang JW, Fan B, Zhang WD (2011) Biomass and nutrients of Pinus massoniana plantations in southern China: simulations for different managing practices. J Food Agr Environ 9:689-693

Zeng ZQ, Wang SL, Zhang CM, Gong C, Hu Q (2013) Carbon storage in evergreen broad-leaf forests in mid-subtropical region of China at four succession stages. J For Res 24:677-682. doi:10.1007/s11676013-0404-3 